Jurnal Pengabdian dan

Penelitian Kepada Masyarakat

(JPPM)

\title{
PENGUATAN MASYARAKAT DI MASA PANDEMI COVID 19: KESEHATAN MENTAL PELAJAR
}

\author{
Santoso Tri Raharjo \\ santoso.tri.raharjo@unpad.ac.id
}

Pusat Studi CSR, Kewirausahaan Sosial, \& Pemberdayaan Masyarakat, Universitas Padjadjaran

\begin{abstract}
Abstrak
Penguatan masyarakat yang menjalan proses adaptasi di tengah situasi dan dampak Pandemi Covid 19 menjadi hal penting saat ini. Banyak masyarakat yang terdampak dengan situasi pandemi saat, ada yang berhasil dan ada yang memerlukan pertolongan dan penguatan. Keperdulian di antara sesama anggota masyarakat sangat diperlukan dalam menghadapi bencana non alam ini. Tidak terkecuali dengan pihak perguruan tinggi, dalam hal ini civitas akademika Universitas Padjadjaran, dengan berbagai sumber daya yang dimiliki dapat mengambil peran penting memperkuat kemampuan masyarakat agara dapat menjalani kehidupan di tengah pandemi cobid 19 ini. Berbagai program dan kegiatan keperdulian pengabdian masyarakat dapat diintegrasikan dengan pembelajaran dan riset. Salah satunya melalui kuliah kerja nyata mahasiswa (KKNM), walaupun dilaksanakan secara virtual. Pemberian informasi dan pengetahuan mengenai pola hidup sehat dan bersih (PHBS) atau penerapan protokol kesehatan (prokes) untuk mencegah penyebaran Covid-19, merupakan salah satu bentuk dari upaya memperkuat kelompok-kelompok masyarakat. Demikan pula dengan cara-cara menghadapi situasi pemberitaan tentang pandemi secara jernih, serta memilah pemberitaan yang valid agar tidak mengganggu kestabilan mental. Hal ini juga merupakan aspek perlu diperkuat, apalagi di era dijital yang makin masif dan kemajuan teknologi informasi dan penggunaan media sosial massal.
\end{abstract}

Kata kunci: pandemi, penguatan, masyarakat

\begin{abstract}
Strengthening people who undergo the adaptation process amidst the situation and the impact of the Covid 19 Pandemic is currently important. Many people were affected by the current pandemic situation, both in the economic, education and health sectors, some were successful and some needed help and strengthening. Concern among fellow community members is needed in dealing with this non-natural disaster. The higher education institutions are no exception, in this case the Padjadjaran University academic community, with its various resources, can play an important role in strengthening the ability of the community so that they can live life in the midst of this Cobid 19 pandemic. Various community service programs and activities can be integrated with learning and research. One of them is through student real work lectures (KKNM), although it is implemented virtually. Providing information and knowledge about healthy and clean lifestyles (PHBS) or the application of health protocols (prokes) to prevent the spread of Covid-19, is one form of efforts to strengthen community groups. Likewise, by dealing with the news situation about the pandemic clearly, and sorting out valid news so as not to disturb mental stability. This is also an aspect that needs to be strengthened, especially in the increasingly massive digital era and advances in information technology and the use of mass social media.
\end{abstract}

Key words: pandemic, strengthening, community 


\begin{tabular}{|c|c|c|c|c|}
\hline $\begin{array}{c}\text { Jurnal Pengabdian dan } \\
\text { Penelitian Kepada Masyarakat } \\
\text { (JPPM) }\end{array}$ & $\begin{array}{c}\text { e ISSN: } 2775-1929 \\
\text { p ISSN: } 2775-1910\end{array}$ & Vol. 2 No.1 & Hal: $56-70$ & April 2021 \\
\hline
\end{tabular}

\section{PENDAHULUAN}

Manusia dipaksa untuk mengubah pola dan gaya hidup mereka untuk bertahan hidup di tengah Pandemi Covid 19 ini. Kemampuan yang bijak akan literasi media sosial dan teknologi informasi seakan menjadi senjata dan kendaraan utama keberhasilan hidup di dunia saat ini. Sebagian masyakat ada yang berhasil, ada pula yang terganggu dalam menghadapi situasi pandemi ini. Kelompok rentan makin bertambah dan mulai tergerus dengan kemajuan jaman saat ini. Bahkan muncul asumsi bahwa pintar dan cerdas saja tidak cukup, jika tidak mampu memanfaatkan kemajuan teknologi informasi.

Namun demikian, banyak pula warga masyarakat yang tidak terlalu perduli dengan perkembangan pandemi covid 19. Demikian masyarakat kecil dan menengah yang sebagian besar tinggal di perdesaan, terkadang tidak perduli dengan perkembangan jaman dan wabah covid 19. Mereka harus tetap memenuhi penghidupan anggota keluarga, mereka terus menjalani kehidupan mereka. Di tengah kesibukan banyak orang dengan pemberitaan pandemi. Sebagian warga masyarakat berjuang, bertahan, dan berkreasi untuk melanjutkan kehidupan mereka. Seakan mereka tidak ingin larut dengan situasi Pandemi Covid 19 yang melanda Indonesia dan dunia saat ini. Mereka bahkan menginspirasi untuk terus bergerak ke depan 'move on', seolah virus Covid 19 tidak mengganggu langkah mereka. Amati lebih dekat lalu cermati, bagaimana orang-orang bermental 'pejuang' terus bertahan dan berkreasi menjalani hidupnya. Banyak pelajaran penting yang dapat dipetik dari upayausaha mereka menjalani kehidupan mereka. Kesulitan dan pengalaman hidup mereka dapat menginspirasi dan memberi bahan pembelajaran bagi siapa saja yang mau belajar dan berusaha. Walau terkadang para pejuang dan 'pengusaha kecil' bermental baja ini tidak menyadarinya apa yang mereka lakukan.

Perlu keberanian yang santun untuk mendekati dan berdialog dengan mereka; menggali cerita di balik perjuangan mereka. Hanya orangorang yang berhati 'terbuka' untuk dapat mendekati dan berdialog dengan mereka. Hanya orang-orang yang memiliki pandangan kekuatan (strength perspective), bagaimana mereka memanfaatkan potensi dan sumber yang pada diri dan lingkungan mereka. Bisa jadi mereka baru memanfaatkan sebagian kecil dari sumber dan potensi mereka, tetapi mereka tetap bertahan dan berjuang. Mereka bukan 'a loser' (pecundang).

Sebagian besar orang mungkin tidak terlalu perduli dengan aktifitas sebagian orang yang terus berusaha dan berbisnis. Hanya karena skala aktifitas atau usahanya kecil. Mungkin juga karena sebagian besar orang lebih suka 'menoleh' dan 'memperhatikan' hal-hal yang besar dan wah, yang 'trending topic', yang banyak dibicarakan banyak orang. Sehingga seolah tertinggal kalau dirinya tidak ikut menjadi bagian dari hal tersebut. Mereka bahkan secara tidak sadar ikut menjadi bagian dengan menyebarluaskan pemberitaan yang seringkali mereka sendiri tidak mengerti isi dan dampak dari penyebarluasan informasi tersebut; bagi dirinya dan orang lain. Seolah dirinya telah berjasa, karena menjadi bagian dari penyebarluasan informasi tersebut. Dirinya hanya menjadi 'pengekor'; terbawa situasi dan hanya mengikuti saja. Ini adalah situasi menyedihkan dan mengkhawatirkan di tengah kesulitan hidup masyarakat dan bangsa saat. Bangsa ini membutuhkan orang-orang yang berani bersikap dan bertindak mandiri, otonom, dan merdeka untuk kelangsungan hidup diri, keluarga, dan bangsa Indonesia saat ini dan ke masa depan. Mulailah memandirikan diri dari hal-hal kecil dan dari diri sendiri.

Tulisan ini mencoba mendeskripsikan salah satu upaya penguatan masyarakat di masa pandemi, khususnya pada kelompok pelajar, Pada masa pademi Covid 19 ini, proses pembelajaran dilakukan secara daring (dalam janingan). Namun demikian situasinya tidak semudah meindahkan proses pembelajaran dari luring (luar jaringan) ke daring. Banyak prasyarat dan kondisi yang perlu disiakan, baik pelajar maupun keluarganya. Situasi ini tersebut tentunya menimbulkan tekanan (stres) yang mengganggu proses pembelajaran yang akan dilakukan. Mereka memerlukan bantuan dan dukungan agar siap menjalani pembelajaran secara daring. Mereka perlu mitra dialog dan diskusi untuk saling berbagi dan mencurahkan perasaannya. 


\begin{tabular}{|c|c|c|c|c|}
\hline $\begin{array}{c}\text { Jurnal Pengabdian dan } \\
\text { Penelitian Kepada Masyarakat } \\
\text { (JPPM) }\end{array}$ & $\begin{array}{c}\text { e ISSN: 2775 - 1929 } \\
\text { p ISSN: } 2775-1910\end{array}$ & Vol. 2 No.1 & Hal: $56-70$ & April 2021 \\
\hline
\end{tabular}

\section{METODE}

Metode deskriptif dengan riset aksi dipergunakan dalam penulisan kajian ini. Kegiatan atau aksi dilakukan setelah melalui proses asesmen terlebih dahulu, kemudian dilanjutkan dengan perancangan kegiatan, dan evaluasi. Penggunaan media sosial dimanfaatkan sebagai media edukasi dan konsultasi bagi pelajar dalam rangka mencegah tekanan-tekanan selama proses pembelajaran.

\section{HASIL DAN PEMBAHASAN}

Proses dan interaksi antar sesama manusia akan makin saling menguatkan dan makin kokoh manakala setiap diri memiliki pandangan 'positif' terhadap setiap manusia dan lingkungannya. Strength perpective merupakan salah satu pandangan bahwa setiap manusia memiliki sumber dan kekuatan. Walaupun dalam situasi Pandemi Covid 19, saat ini perspektif kekuatan (strength perspective) memberi cara pandang yang positif terhadap suatu situasi atau kondisi apapun. Sehingga melalui strength perspective, setiap diri manusia akan memiliki pandangan berimbang; yang tidak hanya selalu berpandangan negatifistik semata. Sebagaimana dikemukakan oleh Raharjo (2019) bahwa pandangan strength perspective sangatterkait dengan prinsip atau konsep pemberdayaan (empowerment).

Empowerment sebagaimana didefinisikan oleh Barker (1995) yaitu "proses pertolongan individual, keluarga, kelompok, dan komunitas untuk meningkatkan personal, interpersonal, sosioekonomi, dan kekuatan politik mereka serta untuk membangun pengaruh $\mathrm{ke}$ arah perbaikan lingkungan mereka". Perspektif kekuatan sangat berguna dalam kehidupan, terutama juga bagi calon pekerjaan sosial yang berlatih dalam melakukan proses assessment, intervention, dan evaluasi bagi proses pertolongan sosial. Perspektif ini tekanannya pada kemampuan, nilai-nilai, kepentingan, keyakinan, sumber-sumber, kelengkapan, dan aspirasi orang.

Saleebey (1995), menyebutkan terdapat emam pedoman prinsipil perspektif kekuatan (strength perspective), yaitu:

1. Every individual, group, family, and community has strengths.
2. Trauma and abuse, illness and struggle may be injurious, but they also be sources of challenge and opportunity

3. Assume ths you do not know the upper limits of the capacity to grow and change and take individual, group, and community aspirations seriously.

4. We best serve clients by collaborating with them.

5. Every environment is full of resources

6. Care, caretaking, and context are important

Perspektif kekuatan mengakui bahwa setiap individu, kelompok, keluarga, organisasi dan masyarakat (IKKOM) tentunya memiliki tantangan, masalah, dan kesulitan-kesulitannya sendiri. Dan setiap IKKOM memiliki cara dan sumber untuk mengatasi segala tantangan, masalah, dan kesulitankesulitan tersebut. Salah satu manfaat besar dari perspektif kekuatan adalah bahwa fokus perhatiannya pada sumber-sumber dan assets yang individu-individu, kelompok, keluarga, organisasi dan masyarakat miliki untuk menghadapi tantangan mereka.

Perspektif kekuatan mengakui kekuatan individu dan kemampuan untuk mengatasi masalah, dan kesadaran dalam penggunaan kekuatan klien adalah bagian dari dasar teori dan praktek pekerjaan sosial. Dimana menurut NASW (2005) bahwa strength perspective adalah:

"The strengths perspective recognizes an individual's strengths and abilities to cope with problems; and awareness and use of the client's strengths is part of the foundation of social work theory and practice."

Strength based perspective merupakan landasan yang baik untuk praktik pekerjaan sosial, yang menurut Saleebey (1992) dalam Cowger (1994: 263) berpendapat bahwa relevansi dari perspektif kekuatan merupakan "good basic social work practice".

Dikatakan sebagai dasar yang baik dalam praktek pekerjaan sosial dikarenakan strength based perspective membuat klien percaya bahwa dirinya memiliki kekuatan. Seperti yang diungkapkan oleh Saleebey:

"The strengths approach obligates us to 


\begin{tabular}{|c|c|c|c|c|}
\hline $\begin{array}{c}\text { Jurnal Pengabdian dan } \\
\text { Penelitian Kepada Masyarakat } \\
\text { (JPPM) }\end{array}$ & $\begin{array}{c}\text { e ISSN: } 2775-1929 \\
\text { p ISSN: } 2775-1910\end{array}$ & Vol. 2 No.1 & Hal: $56-70$ & April 2021 \\
\hline
\end{tabular}

understand - to believe - that everybody (no exceptions here) has external and internal assets, competencies, and resources."

Perspektif kekuatan mewajibkan kita untuk memahami atau percaya bahwa semua orang (tidak ada pengecualian di sini) memiliki aset eksternal dan internal, kompetensi, dan sumber daya.

Pedro Rankin (2006:10) melakukan identifikasi mengenai tiga kecenderungan praktisi untuk fokus pada kekuatan:

1. To tap client strengths effectively, practitioners must be sensitive to them and skillful in utilizing them in the service of accomplishing case goals.

2. Selectively attending to pathology impairs a social worker's ability to discern clients' potential for growth. Although social workers fervently espouse the belief that human beings have the right and opportunity to develop their potentialities, the tendency to focus on pathology undermines that very value commitment.

3. A large proportion of clients need help in enhancing their self-esteem as a result of excessive attendance to pathology. Troubled by self-doubts, feelings of inadequacy, and even feelings of worthlessness, their lack of self-confidence and self respect underlies so many dysfunctional, cognitive, emotional and behavioral patterns, including a fear of failure, depression, social withdrawal, alcoholism, and hypersensitivity to criticism, to name just a few."

Strength based perspective ditekankan pada kekuatan yang paling efektif yang dimiliki oleh klien, dimana praktisi pekerja sosial harus peka terhadap mereka dan terampil dalam memanfaatkanya untuk pencapaian tujuan. Selektif dalam memperhatikan kelemahan dapat mengganggu pekerja sosial dalam membedakan potensi yang dapat tumbuh pada klien. Walaupun pekerja sosial mendukung keyakinan bahwa setiap manusia memiliki hak dan kesempatan untuk mengembangkan potensi yang dimilikinya, dimana fokus pada patologi dapat menggali komitmen yang sangat bernilai. Dimana sebagian besar klien membutuhkan bantuan dalam meningkatkan harga diri yang mereka miliki akibat dari kehadiran banyaknya kelemahan. Gangguan yang datang dari keraguan diri, perasaan tidak mampu, dan bahkan perasaan tidak berharga, kurang percaya diri dan harga diri sehingga membentuk pola disfungsional, kognitif, emosi dan perilaku, termasuk rasa takut gagal. Cowger (1994: 265) menyatakan:

a strength perspective of assessment provides structure and content for examination of realizable alternatives, for the mobilization of competencies that can make things different, and for the building of self-confidence that stimulates hope

Assessmen berdasarkan perspektif kekuatan memberikan struktur (jaringan relasi) dan konten untuk mengidentifikasi alternatif-alternatif sumber, solusi, dan metode yang dapat ujudkan dalam mengtasi masalah. Memanfatkan dan mengharagai berbagai kemampuan beragam, sehingga terbangun kepercayaan diri pada diri klien, dan mendorong klien untu menghargai berbagai potensi yang ada di sekitar diri mereka sebagai modal dasar untuk meraih cita dan harapan mereka ke depan.

\section{Kegiatan Penguatan Masyarakat: Penguatan Kesehatan Mental Pelajar}

\section{Analisis Situasi}

Pandemi Covid-19 membuat pemerintah terpaksa menutup sekolah dan Universitas 19 (WHO, 2020). Hal tersebut dilakukan untuk mengurangi angka penyebaran covid-19 yang semakin memuncak. Saat surat edaran dikeluarkan, mahasiswa pun berbondong-bondong untuk pulang ke kota asal (Winahyu, 2020). Masyarakat pun diminta untuk tidak pergi kemana-mana atau tetap berdiam diri dirumah. Apabila masyarakat ingin keluar rumah diharapkan untuk tetap mengikuti protokol kesehatan yang ada. Selama beberapa bulan pertama virus ini muncul, tagar stay at home bermunculan di media sosial. Hal ini dilakukan untuk memberikan edukasi pada masyarakat untuk tetap mengikuti peraturan yang ada juga memberikan semangat secara virtual.

Aktivitas yang dilakukan pada akhirnya dilakukan secara online baik itu pekerjaan maupun kegiatan pembelajaran (Firman, F., \& Rahayu, S., 


\begin{tabular}{|c|c|c|c|c|}
\hline $\begin{array}{c}\text { Jurnal Pengabdian dan } \\
\text { Penelitian Kepada Masyarakat } \\
\text { (JPPM) }\end{array}$ & $\begin{array}{c}\text { e ISSN: } 2775-1929 \\
\text { p ISSN: } 2775-1910\end{array}$ & Vol. 2 No.1 & Hal: $56-70$ & April 2021 \\
\hline
\end{tabular}

2020). Para mahasiswa pun kembali beradaptasi dengan keadaan yang baru. Di bulan pertama mereka kembali menyusun agenda mereka yang berubah karena pandemi. Sebelumnya, sudah banyak sekali rencana kegiatan yang akan dilakukan tetapi dalam kondisi ini mahasiswa dihadapkan pada beberapa pilihan yaitu menunda, membatalkan atau tetap menjalaninya tetapi dengan sistem yang baru. Bukan suatu hal yang mudah untuk menyusun sebuah rencana apalagi hal tersebut terjadi secara mendadak.

Selain menyusun rencana yang tertunda, mahasiswa harus beradaptasi dengan sistem pembelajaran yang ada. Saat berada dirumah, mereka pasti harus menyusun jadwal yang baru dikarenakan menyesuaikan dengan kegiatan yang biasa dilakukan dirumah seperti membantu pekerjaan rumah dan kegiatan lainnya. Jadwal yang kadang berubah membuat mereka harus siap apabila ada pertemuan dadakan. Tugas-tugas yang diberikan pun harus tetap mereka jalankan secara tepat waktu. Tantangan yang dihadapi selain waktu adalah fasilitas yang terbatas. Saat di kampus, mahasiswa belajar secara langsung sedangkan kali ini mereka harus belajar dengan menggunakan aplikasi zoom dan google meet (Darosha, 2020). Kendala sinyal dan kuota pun menjadi hal yang tak jarang ditemui (Watiknas, 2020).

Rasa jenuh seakan menjadi teman bagi mahasiswa setiap harinya (Brooks et al., 2020 dalam Chao, 2020). Mereka yang terbiasa berkegiatan di luar rumah kini harus tetap berada dirumah sebagai upaya pencegahan penularan Covid-19. Pemberitaan serta informasi diluar sana terkadang dapat memicu rasa takut berlebih sehingga dapat menyebabkan timbulnya emosi negatif yang berbahaya bagi kesehatan mental maupun fisik. Emosi negatif yang timbul akibat pandemi Covid-19 juga ditemukan pada pelajar yang mengisi asesmen, dimana $75 \%$ pelajar merasa burnout dan $60 \%$ merasa insecure.

\section{Tujuan dan Manfaat Kegiatan}

Tujuan dari kegiatan edukasi kesehatan mental pada pelajar ini adalah:

a. Untuk membantu pelajar dalam mengatasi masalah yang dirasakan ketika Pandemi Covid-19 ini dengan menjadi teman untuk bercerita dan membagikan konten-konten terkait kesehatan mental

b. Mengetahui gambaran kondisi kesehatan mental para pelajar dalam Pandemi Covid-19

c. Meningkatkan pengetahuan pelajar mengenai kesehatan mental dan cara coping terutama ketika merasa insecure dan burnout.

Sedangkan manfaat dari kegiatan ini diharapkan dapat membantu meringankan beban pelajar dan menjadi ruang edukasi baru bagi pelajar terkait kesehatan mental.

\section{Metode Pelaksanaan}

Metode yang digunakan pada pelaksanaan kegiatan KKN ini yaitu sharing section yang dilakukan melalui live instagram @bait.ceritaa. Pelaksanaan kegiatan berbagi sebuah bait cerita dengan judul "Fight for Your Mental Health in Pandemic' dilakukan sebanyak dua kali dimana kegiatan pertama mengundang penyintas mental di masa pandemi dan kegiatan kedua mengundang narasumber yang membahas langsung dari prinsip ilmu psikologi. Tahap kegiatan sebagai berikut:

a. Tahap Persiapan

Pada tahap persiapan, pada tanggal 28 Desember 2020 seluruh mahasiswa pelaksanaan KKN melakukan pertemuan perdana bersama dosen pembimbing lapangan untuk berkenalan satu sama lain serta memberikan pengantar dan gambaran kegiatan KKN, kemudian melakukan pembagian kelompok kecil sesuai dengan topik yang diambil. Selanjutnya pada tanggal 29 Desember 2020, kami melakukan first meet bersama kelompok kecil untuk mematangkan topik dan membuat timeline kegiatan yang akan dilakukan. Pada tanggal 30 Desember, kami membuat akun instagram yang bernama @bait.ceritaa sebagai wadah untuk pelaksanaan kegiatan KKN topik kesehatan mental. Pada tanggal 2-4 Januari 2021 kami melakukan asesmen perihal topik yang akan dibahas dengan tujuan apa yang akan kami sampaikan sesuai dengan apa yang dibutuhkan 


\begin{tabular}{|c|c|c|c|c|}
\hline $\begin{array}{c}\text { Jurnal Pengabdian dan } \\
\text { Penelitian Kepada Masyarakat } \\
\text { (JPPM) }\end{array}$ & $\begin{array}{c}\text { e ISSN: 2775 - 1929 } \\
\text { p ISSN: } 2775-1910\end{array}$ & Vol. 2 No.1 & Hal: $56-70$ & April 2021 \\
\hline
\end{tabular}

masyarakat. Kemudian pada tanggal 11 Januari 2021, pelaksanaan pelepasan mahasiswa secara resmi untuk memulai kegiatan KKN oleh Rektorat. Selama proses perancangan kegiatan live instagram pada tanggal 5 Januari sampai 30 Januari, kami memberikan konten edukatif melalui instagram mengenai topik kesehatan mental yaitu burnout dan insecure.

b. Tahap Pelaksanaan

Pada tahap pelaksanaan, pada tanggal 16-21 Januari 2021 penulis melakukan wawancara bersama mitra dalam rangka mencari data yang konkrit mengenai kesehatan mental di daerah masingmasing dan melakukan upaya untuk menangani permasalahan dari hasil yang sudah didiskusikan sebelumnya. Hasil yang didapatkan setelah berdiskusi bersama mitra dan juga hasil diskusi bersama kelompok kecil, kami memutuskan untuk membuat kegiatan sharing secara online, kegiatan tersebut kami lakukan melalui platform live instagram yang dilakukan sebanyak dua kali dengan judul kegiatan "Fight for Your Mental Health in Pandemic'. Publikasi yang kami lakukan dengan mengunggah poster di instagram melalui instagram story dan feeds serta mengajak teman juga keluarga. Kegiatan live instagram pertama dilakukan pada tanggal 31 Januari 2021 dimana kami melakukan kegiatan sharing bersama penyintas. Kemudian kami melakukan live instagram kedua pada tanggal 7 Februari 2021, kegiatan tersebut mengundang mahasiswa psikologi tingkat akhir untuk sharing mengenai insecure dan burnout berdasarkan prinsip ilmu psikologi.

c. Tahap Evaluasi

Pada tahap evaluasi pelaksanaan kegiatan, kami melakukan diskusi menggunakan google meet untuk membahas kendala atau permasalahan yang terjadi selama pelaksanaan kegiatan. Selain melakukan diskusi, kami juga membuat asesmen berupa kuesioner evaluasi untuk dibagikan ke partisipan. Kuesioner evaluasi dilakukan untuk mengetahui capaian dari tujuan kegiatan serta mengetahui feedback untuk perbaikan kegiatan kedepannya.

\section{Subjek, Lokasi, dan Waktu}

Pelajar dengan rentang usia 17-21 tahun yang terdiri dari para pengikut Instagram @bait.ceritaa, mitra dari tiap anggota kelompok, dan pengguna Instagram secara umum. Kegiatan edukasi kesehatan mental dilakukan melalui media sosial Instagram dengan pertimbangan bahwa Instagram merupakan media sosial yang praktis dan banyak digunakan oleh kelompok usia sasaran yaitu 18 - 22 tahun dengan total persentase 37,3 persen atau sekitar 23 juta pengguna. Kegiatan KKN-PPM virtual ini dilaksanakan pada tanggal 28 Desember 2020 sampai 10 Februari 2021. Sebagaimana terlampir dalam tabel berikut:

Tabel 1. Rekapituasi Kegiatan Penguatan Masyarakat:

Edukasi Penguatan Kesehatan Mental Bagi Pelajar

\begin{tabular}{|c|c|c|c|}
\hline Kegiatan & Konten & Isi Konten & Keterangan \\
\hline $\begin{array}{l}\text { Membuat akun } \\
\text { instagram }\end{array}$ & $@$ baitcerita & & \\
\hline \multirow[t]{2}{*}{ Asesmen } & $\begin{array}{l}\text { Question Box (setiap } \\
\text { orang minimal } 2 \\
\text { partisipan) }\end{array}$ & $\begin{array}{l}\text { Burnout, Anxiety, } \\
\text { Insecure, } \\
\text { Depresi }\end{array}$ & Snapgram \\
\hline & $\begin{array}{l}\text { Membuat asesmen } \\
\text { melalui Google Form }\end{array}$ & $\begin{array}{l}\text { Berdasarkan hasil dari } \\
\text { question box }\end{array}$ & Media sosial \\
\hline
\end{tabular}




\begin{tabular}{|c|c|c|c|c|}
\hline $\begin{array}{c}\text { Jurnal Pengabdian dan } \\
\text { Penelitian Kepada Masyarakat } \\
\text { (JPPM) }\end{array}$ & $\begin{array}{c}\text { e ISSN: 2775 - 1929 } \\
\text { p ISSN: } 2775-1910\end{array}$ & Vol. 2 No.1 & Hal: $56-70$ & April 2021 \\
\hline
\end{tabular}

\begin{tabular}{|c|c|c|c|}
\hline Kegiatan & Konten & Isi Konten & Keterangan \\
\hline $\begin{array}{c}\text { Mengolah data \& } \\
\text { membuat script poster }\end{array}$ & & & Google meet \\
\hline $\begin{array}{c}\text { Mencari Konten } \\
\text { mengenai kesehatan } \\
\text { mental }\end{array}$ & & & \\
\hline \multirow{4}{*}{ Konten Minggu ke-1 } & \multirow{2}{*}{ Editing : Introduction } & $\begin{array}{c}\text { - Fenomena } \\
\text { - Mental Health }\end{array}$ & Instagram Story \\
\hline & & Hasil Question box & Feed Instagram \\
\hline & $\begin{array}{l}\text { UPLOAD IG : } \\
\text { Introduction }\end{array}$ & & Feed Instagram \\
\hline & $\begin{array}{l}\text { Editing : Sharing Cerita } \\
\text { melalui Poster }\end{array}$ & $\begin{array}{c}\text { Berdasarkan } \\
\text { pengalaman orang lain }\end{array}$ & Feed Instagram \\
\hline \multicolumn{4}{|l|}{$\begin{array}{l}\text { Mencari Konten } \\
\text { mengenai insecure }\end{array}$} \\
\hline \multirow{4}{*}{ Konten Minggu ke-2 } & $\begin{array}{l}\text { Editing : Introduce } \\
\text { topik } 1\end{array}$ & $\begin{array}{l}\text { Definisi, jenis-jenis, } \\
\text { penyebab, fun fact \& } \\
\text { Sumber }\end{array}$ & Feed Instagram \\
\hline & UPLOAD IG : topik 1 & & Feed Instagram \\
\hline & Editing : Coping topik 1 & $\begin{array}{c}\text { Cara mengatasinya \& } \\
\text { Sumber }\end{array}$ & Feed Instagram \\
\hline & $\begin{array}{l}\text { UPLOAD IG : coping } \\
\text { topik } 1\end{array}$ & & Feed Instagram \\
\hline $\begin{array}{l}\text { Membahas kegiatan } \\
\text { Instagram Live }\end{array}$ & & & Google meet \\
\hline \multicolumn{4}{|l|}{$\begin{array}{l}\text { Mencari Konten } \\
\text { mengenai burnout }\end{array}$} \\
\hline \multirow{6}{*}{ Konten Minggu ke-3 } & $\begin{array}{l}\text { Editing : Introduce } \\
\text { topik } 2\end{array}$ & $\begin{array}{c}\text { Definisi, jenis-jenis, } \\
\text { penyebab, fun fact \& } \\
\text { Sumber }\end{array}$ & Feed Instagram \\
\hline & UPLOAD IG : topik 2 & & Feed Instagram \\
\hline & Coping topik 2 & $\begin{array}{c}\text { Cara mengatasinya \& } \\
\text { Sumber }\end{array}$ & Feed Instagram \\
\hline & $\begin{array}{l}\text { UPLOAD IG : coping } \\
\text { topik } 2\end{array}$ & & Feed Instagram \\
\hline & Editing : Coming soon & & \\
\hline & UPLOAD : Coming & & Feed Instagram \\
\hline
\end{tabular}




\begin{tabular}{|c|c|c|c|c|}
\hline $\begin{array}{c}\text { Jurnal Pengabdian dan } \\
\text { Penelitian Kepada Masyarakat } \\
\text { (JPPM) }\end{array}$ & $\begin{array}{c}\text { e ISSN: 2775 - 1929 } \\
\text { p ISSN: } 2775-1910\end{array}$ & Vol. 2 No.1 & Hal: 56 - 70 & April 2021 \\
\hline
\end{tabular}

\begin{tabular}{|c|c|c|c|}
\hline Kegiatan & Konten & Isi Konten & Keterangan \\
\hline & Soon live & \multirow{2}{*}{$\begin{array}{c}\text { Narasumber : Penyintas } \\
\text { Gangguan Kesehatan } \\
\text { Mental }\end{array}$} & \\
\hline & Live Instagram & & Feed Instagram \\
\hline \multicolumn{4}{|l|}{$\begin{array}{l}\text { Mencari Konten } \\
\text { mengenai fun fact } \\
\text { mental health }\end{array}$} \\
\hline \multirow{5}{*}{ Konten Minggu ke-4 } & $\begin{array}{c}\text { Editing konten } \\
\text { mengenai Fun fact }\end{array}$ & $\begin{array}{c}\text { Fakta menarik tentang } \\
\text { mental health }\end{array}$ & Feed Instagram \\
\hline & Editing : Coming soon & & \\
\hline & $\begin{array}{l}\text { UPLOAD : Coming } \\
\text { soon live }\end{array}$ & \multirow{2}{*}{$\begin{array}{l}\text { Narasumber: Mental } \\
\text { Health Enthusiast }\end{array}$} & Feed Instagram \\
\hline & Live Instagram & & Feed Instagram \\
\hline & $\begin{array}{l}\text { Menghubungi } \\
\text { narasumber }\end{array}$ & & \\
\hline \multirow{2}{*}{ Laporan kelompok } & Tertulis & & \\
\hline & Youtube & & \\
\hline
\end{tabular}

Sumber: Pengabdian pada masyarakat (KKN Virtual, Januari-Februari 2021)

\section{Pelaksanaan Pengabdian Pada Masyarakat: Edukasi Penguatan Kesehatan Mental Bagi Pelajar}

a. Persiapan Kegiatan: Assesment Asesmen pertama yang kami lakukan pada tanggal 31 Desember 2020 - 2 Januari 2021 adalah asesmen berupa pertanyaan mengenai apa yang dirasakan pelajar di tengah pandemi Covid-19 yang disebarkan melalui akun instagram masing-masing anggota. Kemudian kami melakukan olah data asesmen dan mendapatkan dua hasil tertinggi yaitu, insecure dan burnout. Setelah itu, Kami melakukan asesmen kedua melalui google form yang berisikan pertanyaan tentang dua topik tersebut. Dari google form, didapatkan 83 responden dengan hasil $60 \%$ pelajar merasakan insecure dan $75 \%$ merasakan burnout. Selanjutnya kami mencari dan mengumpulkan informasi yang relevan mengenai kedua topik tersebut. Setelah menemukan hasil, kami memposting secara bertahap sebanyak dua kali seminggu dan melakukan kegiatan sharing melalui Instagram Live bersama penyintas gangguan kesehatan mental dan mental health enthusiast.

Permasalahan Secara Umum:

i. Kegiatan yang serba terbatas karena adanya pandemi membuat pelajar lebih mudah lelah dan khawatir

ii. Kurangnya kepedulian mengenai kesehatan mental dan psikis masing- masing

iii. Kurang terbukanya masyarakat terhadap orang-orang sekitar yang membutuhkan kesehatan mental

pertolongan

iv. Sosialisasi mengenai Edukasi Kesehatan Mental dirasa masih kurang. 


\begin{tabular}{|c|c|c|c|c|}
\hline $\begin{array}{c}\text { Jurnal Pengabdian dan } \\
\text { Penelitian Kepada Masyarakat } \\
\text { (JPPM) }\end{array}$ & $\begin{array}{c}\text { e ISSN: 2775 - 1929 } \\
\text { p ISSN: } 2775-1910\end{array}$ & Vol. 2 No.1 & Hal: $56-70$ & April 2021 \\
\hline
\end{tabular}

Permasalahan yang timbul Akibat Pandemi COVID-19: Penyuluhan atau sosialisasi mengenai pentingnya kesehatan mental tidak bisa dilakukan secara offline. Penguatan melalui edukasi bisa melalui media sosial atau media elektronik lainnya. Harapan Output untuk kegiatan Edukasi Kesehatan Mental: Masyarakat lebih aware dengan kesehatan mental; Pelajar mengetahui informasi dan cara menangani gangguan seperti insecure dan burnout; dan Informasi mudah diterima dan dipahami oleh masyarakat

Analisis Solusi dari Data Permasalahan:

i. Pembuatan konten instagram yang menarik agar pelajar/masyarakat tidak bosan dan lebih mudah menerima informasi mengenai kesehatan mental

ii. Sharing bersama penyintas gangguan kesehatan mental dan mental health enthusiast agar terjadi komunikasi dua arah dengan pelajar/masyarakat dan bisa bertanya dengan leluasa dari orang yang berpengalaman/mengerti dengan bidangnya.

b. Koordinasi dan Konsultasi

Setiap minggunya kami melakukan video conference melalui Zoom dengan DPL untuk mengevaluasi kegiatan yang dilakukan setiap minggunya. Perencanaan kegiatan KKN didasarkan pada tema besar kami, yaitu "Penguatan Masyarakat di Tengah Pandemi Covid19. Penetapan subjek dilakukan terhadap orang-orang terdekat terlebih dahulu dan dicari permasalahan yang terjadi. setelah itu didapatkan penyelesaian yang dianggap efektif, yaitu dengan cara :

i. Menyebarkan Kuesioner mengenai topik utama kami, yaitu insecure dan burnout

ii. Pembuatan media sosial instagram dengan nama bait cerita sebagai wadah untuk memberikan informasi terkait kesehatan mental iii. Membuat konten edukasi mengenai kesehatan mental yang bertujuan untuk melakukan pencegahan mengenai gangguan kesehatan mental lalu diposting ke media sosial instagram bait cerita.

iv. Membuat kegiatan sharing bersama penyintas gangguan kesehatan mental dan mental health enthusiast.

Pelaksanaan kegiatan KKN-PPM 2020 mulai dilaksanakan pada tanggal 28 Desember 2020 sampai dengan 10 Februari 2021, sebelum kegiatan KKN ini dimulai, pada tanggal 28 Desember 2020 dilakukan pembekalan terlebih dahulu yang disampaikan oleh Dosen Pembimbing Lapangan (DPL).

Setelah itu, kegiatan Asesmen pertama dilakukan dari tanggal 31 Desember 2020 hingga 2 Januari 2021 melalui media sosial Instagram masing-masing. Setelah kuesioner sudah diisi oleh subjek KKN, didapatkan dua masalah tertinggi yang dialami pelajar dan mahasiswa yaitu Insecure dan Burnout. Setelah dua masalah tertinggi didapatkan kami melakukan asesmen kedua melalui google form yang berisi tentang dua masalah tersebut pada tanggal 4-6 Januari 2021. Total responden yang mengisi adalah 83 orang, dengan rentang umur 1822 tahun. Hasil yang didapatkan terdapat $60 \%$ mahasiswa yang merasa insecure dan $75 \%$ merasakan burnout.

Dalam Google Form tersebut juga terdapat pertanyaan mengenai cara responden menanggapi insecure dan burnout. Dan menurut respon yang kami baca, ternyata mahasiswa belum mengetahui cara menghadapi insecure dan burnout itu sendiri. Setelah mitra dari masing-masing peserta sudah menyetujui permasalahan yang akan kami angkat, kami mulai memproses informasi mengenai insecure dan burnout dan mulai memposting secara berkala mengenai informasi-informasi mengenai kesehatan mental, insecure, dan juga burnout.

Kemudian, minggu ketiga diakhiri dengan pelaksanaan Instagram Live, yakni penyiaran video secara langsung melalui akun Instagram Bait Cerita yang dapat disaksikan oleh pengikut Instagram Bait Cerita maupun para pemilik akun Instagram lainnya. Live tersebut berjudul "Berbagi Sebuah 


\begin{tabular}{|c|c|c|c|c|}
\hline $\begin{array}{c}\text { Jurnal Pengabdian dan } \\
\text { Penelitian Kepada Masyarakat } \\
\text { (JPPM) }\end{array}$ & $\begin{array}{c}\text { e ISSN: } 2775-1929 \\
\text { p ISSN: } 2775-1910\end{array}$ & Vol. 2 No.1 & Hal: $56-70$ & April 2021 \\
\hline
\end{tabular}

Bait Cerita: Fight for Your Mental Health in Pandemic" yang dilakukan dengan Aurelia Nur Amani, seorang mahasiswa sekaligus penyintas gangguan kesehatan mental yang membagikan pengalamannya serta membahas kedua topik yang menjadi bahasan utama dari akun Instagram Bait Cerita, yakni topik Insecure dan Burnout. Instagram Live ini berjalan lancar dan dihadiri oleh lebih dari 70 orang dengan cara komunikasi dua arah dari pembicara dan penonton melalui sesi tanya jawab seputar pengalaman penyintas terkait permasalahan kesehatan mental.

Pada minggu keempat, dilakukan pengunggahan konten yang mengandung fakta-fakta seputar permasalahan kesehatan mental, yakni terkait Self-Esteem, Coronavirus Anxiety, dan data terkait isu kesehatan mental di dunia. Minggu ini ditutup dengan pelaksanaan Instagram Live "Bait Cerita Kembali Bercerita: Fight for Your Mental Health in Pandemic 2.0". Live ini kali ini dilakukan dengan Ka Nisrina Nur Izzah, seorang alumni Fakultas Psikologi Universitas Padjadjaran yang juga merupakan mental health enthusiast yang membahas kesehatan mental secara umum, Insecure, dan Burnout berdasarkan ilmu psikologi maupun pengalamannya.

Pada minggu ke 5, dikarenakan rangkaian kegiatan KKN-PPM 2020 sudah selesai dilaksanakan, kami melakukan evaluasi berupa kuesioner yang disebar kepada pengikut instagram bait cerita. Setelah hasil evaluasi didapatkan, kami sebagai membuat laporan kegiatan mengenai kegiatan pelaksanaan KKN.

\section{c. Evaluasi}

i. Evaluasi Persiapan Kegiatan Persiapan dilakukan selama kurang lebih satu bulan, terhitung sejak tanggal 29 Desember 2020 sampai dengan tanggal 12 Januari 2021. Persiapan tersebut berlangsung dengan lancar, didukung oleh kesamaan ide dan tujuan kegiatan yang dimiliki oleh masing-masing anggota kelompok. Sehingga, pada rapat kelompok pertama, kami sudah dapat menyusun timeline kegiatan kami untuk memudahkan kami pada saat melaksanakan rangkaian kegiatan ini. ii. Evaluasi Pelaksanaan Kegiatan

Kegiatan dilaksanakan selama kurang lebih satu bulan, terhitung sejak tanggal 13 Januari 2021 sampai dengan tanggal 7 Februari 2021 melalui akun Instagram Bait Cerita. Pada pelaksanaannya, kami mengalami beberapa kali keterlambatan dalam melakukan pengunggahan konten ke akun Instagram tersebut dari timeline kegiatan yang telah kami buat. Namun, hal tersebut tidak terlalu mempengaruhi kelancaran dari kegiatan ini karena kegiatan masih tetap berjalan sesuai target per minggu kami.

Kemudian, pada saat pelaksanaan acara Instagram Live pertama, moderator mengalami kendala teknis dimana perangkat yang digunakan moderator untuk melaksanakan Live tersebut mengalami error saat acara sudah selesai. Sehingga, moderator tidak dapat menyimpan video dari kegiatan Live tersebut. Namun, kami masih menyimpan bukti dokumentasi berupa foto pada saat kegiatan Instagram Live berlangsung.

Pada pelaksanaan acara Instagram Live kedua, moderator mengalami kendala teknis dimana moderator tidak dapat menemukan opsi Live pada perangkat yang digunakan moderator untuk melangsungkan kegiatan Instagram Live tersebut. Sehingga, acara mengalami keterlambatan sekitar 30 menit sampai akhirnya dapat dimulai oleh moderator.

Oleh karena itu, diharapkan agar kedepannya dapat dilakukan perencanaan yang lebih matang serta melakukan geladi terlebih dahulu sebelum kegiatan dilaksanakan untuk mengantisipasi kendala teknis maupun kendala-kendala lainnya pada saat acara berlangsung.

iii. Evaluasi Hasil Pelaksanaan

Berdasarkan pelaksanaan kegiatan KKN yang telah dilakukan selama satu 


\begin{tabular}{|c|c|c|c|c|}
\hline $\begin{array}{c}\text { Jurnal Pengabdian dan } \\
\text { Penelitian Kepada Masyarakat } \\
\text { (JPPM) }\end{array}$ & $\begin{array}{c}\text { e ISSN: 2775 - 1929 } \\
\text { p ISSN: } 2775-1910\end{array}$ & Vol. 2 No.1 & Hal: $56-70$ & April 2021 \\
\hline
\end{tabular}

bulan tersebut, kami menemukan bahwa di luar dari mitra masing-masing anggota kelompok, banyak sekali pelajar yang kesehatan mentalnya terdampak akibat pandemi Covid-19 ini. Namun, banyak pula pelajar yang masih kurang paham terkait permasalahanpermasalahan kesehatan mental yang dialaminya.

Dengan dilaksanakannya kegiatan KKN melalui akun Instagram Bait Cerita, banyak pelajar di lingkungan para anggota kelompok yang teredukasi seputar kesehatan mental, khususnya dalam topik Insecure dan Burnout. Sehingga, diharapkan para pengikut akun Instagram Bait Cerita selanjutnya dapat mengenali jika dirinya maupun orang-orang di sekitarnya tengah mengalami permasalahan kesehatan mental Insecure dan Burnout. Diharapkan pula para pengikut akun Instagram Bait Cerita yang telah teredukasi dapat melakukan langkahlangkah untuk mengatasi permasalahan kesehatan mental Insecure dan Burnout tersebut.

Setelah kegiatan usai dilaksanakan, kami melakukan penyebaran asesmen berupa formulir evaluasi kegiatan berbentuk Google Form kepada para mitra serta para pelajar yang mengikuti akun Instagram Bait Cerita. Asesmen tersebut menghasilkan berbagai respons dari para responden sebagai berikut:

Tabel 2. Hasil Evaluasi Kegiatan

\begin{tabular}{|c|c|c|c|c|c|c|}
\hline \multicolumn{7}{|c|}{ HASIL ASESMEN EVALUASI KEGIATAN } \\
\hline Tanggapan & $\begin{array}{l}\text { Kegiatan } \\
\text { yang } \\
\text { dilakukan } \\
\text { menarik }\end{array}$ & $\begin{array}{l}\text { Saya } \\
\text { memahami } \\
\text { informasi } \\
\text { yang } \\
\text { disampaikan } \\
\text { dengan baik }\end{array}$ & $\begin{array}{l}\text { Informasi } \\
\text { yang } \\
\text { disampaikan } \\
\text { berguna bagi } \\
\text { saya }\end{array}$ & $\begin{array}{l}\text { Kegiatan } \\
\text { Instagram } \\
\text { Live yang } \\
\text { telah } \\
\text { dilaksanakan } \\
\text { bermanfaat } \\
\text { bagi saya }\end{array}$ & $\begin{array}{l}\text { Konten- } \\
\text { konten yang } \\
\text { diunggah } \\
\text { menarik dan } \\
\text { bermanfaat } \\
\text { bagi saya }\end{array}$ & $\begin{array}{l}\text { Pengetahuan } \\
\text { saya akan } \\
\text { kesehatan } \\
\text { mental } \\
\text { bertambah }\end{array}$ \\
\hline Skor & 4,5 & 4,5 & 4,5 & 4,7 & 4,6 & 4,4 \\
\hline Interpretasi & Baik & Baik & Baik & Sangat Baik & Sangat Baik & Baik \\
\hline Total Skor & \multicolumn{6}{|c|}{ 4,21 = Baik } \\
\hline Saran & $\begin{array}{l}\text { Perluasan } \\
\text { pembahasan } \\
\text { topik }\end{array}$ & $\begin{array}{l}\text { Hadirkan } \\
\text { pemateri } \\
\text { yang lebih } \\
\text { baik }\end{array}$ & $\begin{array}{l}\text { Tingkatkan } \\
\text { interaksi } \\
\text { dengan } \\
\text { partisipan }\end{array}$ & $\begin{array}{l}\text { Lakukan } \\
\text { kegiatan } \\
\text { sejenis di } \\
\text { platform lain }\end{array}$ & $\begin{array}{l}\text { Tingkatkan } \\
\text { penyampaian } \\
\text { topik yang } \\
\text { lebih } \\
\text { terstruktur } \\
\text { dan matang }\end{array}$ & \\
\hline
\end{tabular}

Sumber: Pengabdian pada masyarakat (KKN Virtual, Januari-Februari 2021)

Beberapa tanggapan yang didapatkan ialah bahwa kegiatan yang telah dilaksanakan menarik, informasi yang disediakan oleh akun Instagram Bait Cerita disampaikan dengan baik, dapat dipahami dengan mudah, serta dirasa akan berguna bagi para responden, acara Instagram Live yang telah dilaksanakan bermanfaat bagi para responden, konten-konten yang diunggah pada akun Instagram tersebut menarik dan bermanfaat bagi para responden, serta pengetahuan para responden akan 


\begin{tabular}{|c|c|c|c|c|}
\hline $\begin{array}{c}\text { Jurnal Pengabdian dan } \\
\text { Penelitian Kepada Masyarakat } \\
\text { (JPPM) }\end{array}$ & $\begin{array}{c}\text { e ISSN: 2775 - 1929 } \\
\text { p ISSN: } 2775-1910\end{array}$ & Vol. 2 No.1 & Hal: $56-70$ & April 2021 \\
\hline
\end{tabular}

kesehatan mental bertambah.

Selanjutnya, para responden merasa masih terdapat beberapa kekurangan dari kegiatan yang telah dilaksanakan melalui akun Instagram Bait Cerita tersebut. Beberapa di antaranya ialah topik yang dibahas serta media yang digunakan memiliki cakupan yang sempit, penyampaian topik yang kurang terstruktur dan matang, serta kurangnya interaksi, baik dari administrator akun Instagram Bait Cerita maupun narasumber, terhadap pengikut akun Instagram serta partisipan acara Instagram Live Bait Cerita.

\section{Rencana Tindak Lanjut Kegiatan}

Di samping Insecure dan Burnout, masih banyak ditemukan permasalahan-permasalahan kesehatan mental lainnya yang mengalami peningkatan akibat pandemi Covid-19 yang hingga saat ini tak kunjung berhenti. Namun, karena keterbatasan waktu, kelompok kami belum dapat mengakomodasi berbagai permasalahan kesehatan mental lainnya tersebut untuk dijadikan pembahasan secara matang di akun Instagram Bait Cerita.

Sehingga, diharapkan kedepannya akun Instagram Bait Cerita dapat menjadi sumber edukasi modern bagi para pelajar yang hendak mencari pemahaman seputar kesehatan mental maupun wadah bercerita bagi para pelajar yang tengah mengalami permasalahan kesehatan mental, khususnya di masa pandemi Covid-19 ini dengan jangkauan topik maupun partisipan yang lebih luas. Diharapkan pula dengan persiapan yang lebih terstruktur dan matang, akun Instagram tersebut dapat menjadi wadah yang lebih interaktif dengan para pengikut dan partisipan acaranya serta menjadi wadah yang berkelanjutan. Kegiatan KKN-PPM bertema Penguatan Masyarakat dalam Situasi Pandemi Covid-19 dilaksanakan dalam bentuk kegiatan edukasi kesehatan mental kepada pelajar yang dilakukan menggunakan media sosial Instagram. Kegiatan edukasi kesehatan mental terdiri dari posting konten kesehatan mental dan cara mengatasinya serta kegiatan sharing Live Instagram bersama penyintas dan mental health enthusiast. Edukasi kesehatan mental difokuskan pada pembahasan mengenai burnout dan insecure yang didasarkan pada hasil asesmen dan diskusi bersama mitra didapatkan bahwa banyak pelajar merasa burnout dan insecure di tengah Pandemi
Covid-19. Diakhir kegiatan, kami melakukan analisis ketercapaian dari kegiatan edukasi yang dilakukan dengan menggunakan kuesioner evaluasi. Dari asesmen evaluasi didapatkan hasil bahwa partisipan mampu memahami informasi yang disampaikan dengan baik, merasakan manfaat dari kegiatan sharing Live Instagram dan konten yang diberikan, serta merasa pengetahuan mengenai kesehatan mental bertambah, sehingga dapat disimpulkan bahwa kegiatan edukasi kesehatan mental tercapai dari segi tujuan dan manfaatnya bagi masyarakat.

Lancarnya pelaksanaan program KKN-PPM tidak terlepas dari dukungan semua pihak serta kerjasama yang baik antara mahasiswa KKN dengan pihak lainnya seperti mitra $\mathrm{KKN}$, dosen DPL partisipan, dan narasumber. Oleh karena itu, kekompakan harus selalu dijaga dalam setiap pelaksanaan program kerja. Disamping lancarnya pelaksanaan program KKN-PPM virtual, terdapat saran untuk perbaikan kedepan nya antara lain kegiatan edukasi kesehatan mental lebih baik dilaksanakan dengan menghadirkan pemateri yang lebih baik, memperluas topik pembahasan serta menyampaikan topik pembahasan dengan lebih matang dan terstruktur. Selain itu, perlu juga untuk meningkatkan interaksi dengan partisipan supaya dapat terciptanya komunikasi yang lebih baik dan melakukan kegiatan edukasi di beberapa media sosial tidak hanya di Instagram saja.

\section{SIMPULAN}

Kegiatan penguatan masyarakat di masa Pendemi Covid 19 dapat dilakukan dengan berbagai cara. Masih banyak kelompok-kelompok masyarakat yang masih memerlukan dukungan dan bantuan khususnya dalam masa Pandemi Covid-19 ini. Penguatan kelompok pelajar dengan edukasi kesehatan mental merupakan salah satu upaya dari sekian banyak upaya untuk memperkuat sisi kehidupan masyarakat. Pemanfaatan berbagai media sosial khususnya yang dekat dan biasa dipergunakan oleh remaja saat ini. Berbagai media sosial itu dapat dimanfaatkan untuk kelompokkelompok sosial lain yang rentan dan memerlukan bantuan dan dukungan.

Upaya penguatan masyarakat di masa 


\begin{tabular}{|c|c|c|c|c|}
\hline $\begin{array}{c}\text { Jurnal Pengabdian dan } \\
\text { Penelitian Kepada Masyarakat } \\
\text { (JPPM) }\end{array}$ & $\begin{array}{c}\text { e ISSN: 2775 - 1929 } \\
\text { p ISSN: } 2775-1910\end{array}$ & Vol. 2 No.1 & Hal: 56 - 70 & April 2021 \\
\hline
\end{tabular}

Pandemi Covid-19 dapat dilanjutkan pada kelompok-kelompok masyarakat lainnya. Misalkan pada sektor ekonomi, banyak pengangguran baru muncul saat ini. Demikian pula pada kelompokkelompok rentan lainnya, seperti kaum disabilitas, kelompok lanjut usia, dan anak-anak.

\section{DAFTAR PUSTAKA}

Bloom, B. S. ed. et al. (1956). Taxonomy of Educational Objectives: Handbook 1, Cognitive Domain. New York: David McKay

Bradford W. Sheafor, The Professionalization of Baccalaureate-Level Social Work journals.iupui.edu/index.php/advancesinsoc ialwork/article/viewFile/16646/16942

Brooks, S. K., Webster, R. K., Smith, L. E., Woodland, L., Wessely, S., Greenberg, N., \& Rubin, G. J. (2020). The psychological impact of quarantine and how to reduce it: rapid review of the evidence. Lancet (London, England), 395(10227), 912-920. https://doi.org/10.1016/S01406736(20)30460-8

Cormier \& Cormier (1998). Interviewing strategies for helpers (4th ed.) Pasific Grove, CA: Brooks/Cole

Darosha, M. (2020, Maret 23). Google Meet dan Zoom: Media Alternatif saat Work From Home. Retrieved from Tala: https://talamedia.id/tekno/google-meet-danzoom-media-alternatif-saat-work-fromhome/

Dean H. Hepworth, Ronald H. Rooney, \& Jo Ann Larsen (2002). Direct Social Practice, Theory and Skills, 6th. California: Brooks/Cole

Detikinet. (2020). 6 Tips Agar Tetap Produktif Selama Bekerja dan Belajar di Rumah. from: https://inet.detik.com/cyberlife/d4968758/6-tips-agar-tetap-produktifselama-bekerja-dan-belajar-di-rumah

Dubois, B., and Miley, K. K. (1999). Social Work: An empowering profession ( $3^{\text {rd }}$ ed.) Boston: Allyn and Bacon.

Estriyanto Y. (2020). Penguatan Ketahanan Masyarakat terhadap PandemiCovid-19
Dengan Program Kuliah Kerja Nyata.

Dedikasi: community Service Reposrt, 2(2), 66-78.

Firman, F., \& Rahayu, S. (2020). Pembelajaran online di Tengah Pandemi Covid19. Indonesian Journal of Educational Science (IJES), 2(2), 81-89.

Graybeal, Clay. (2001). Strengths-Based Social Work Assessment: Transforming in The Dominant Paradigm. Families in Society: The Journal of Contemporary Human Services. Families International Inc.

Graybeal, Clay. (2001). Strengths-Based Social Work Assessment: Transforming in The Dominant Paradigm. Families in Society: The Journal of Contemporary Human Services. Families International Inc.

Hepworth, D., Rooney, R., and Larsen, J. (2002). Direct Social Work Practice: Theory and Skills ( $6^{\text {th }}$ ed.). Pasific Grove, CA: Brooks/Cole.

Hill, C.E \& Obrien, K.M. (2004). Helping skills: Facilitating Exploration, insight and action (2 nd). Washinton, DC: Amarican Psychologcal Association.

Johnson dan Schwarzt (1991). Social Welfare: A Response to Human Needs. Boston: Allyn \& Bacon

Jon Bailey \& Mary Burch (2010). 25 Essential Skills \& Strategies for the Professional Behavior Analiyst. New York, Routledge Taylor and francis Group, LLC..

Kadushin \&Kadushin, (1997). The Social Work Interview (4 th ed). New York: Columbia University Press

Karen K. Kirst-Ashman and Grafton H. Hull, Jr, (2009). Generalist Practice with Organization and Communites, Fouth Edition. Brooks/Cole:California

Karls, James, and Karin Waandrei, (1988). Person in Environment: A System for Describing, Classifying and Coding Problems of Social Functioning. Silver Spring. MD:NASW,

Kirs-Ashman, K., and Hull, G. (1993). Understanding Generalist Practice. Chicago:Nelson-Hall. 1999. Understanding Generalist Practice $2^{\text {nd }}$ Edition. Nelson-Hall Pub. : Chicago 


\begin{tabular}{|c|c|c|c|c|}
\hline $\begin{array}{c}\text { Jurnal Pengabdian dan } \\
\text { Penelitian Kepada Masyarakat } \\
\text { (JPPM) }\end{array}$ & $\begin{array}{c}\text { e ISSN: 2775 - 1929 } \\
\text { p ISSN: } 2775-1910\end{array}$ & Vol. 2 No.1 & Hal: 56 - 70 & April 2021 \\
\hline
\end{tabular}

Kirst-Ashman, Hull, Vogel. 1999. Student Manual of Classroom Exercises and Study Guide for Understanding Generalist Practice $2^{\text {nd }}$ Edition. Nelson-Hall Pub. : Chicago

Linda Cummins, Judith Sevel \& Laura Pedrick, (2006), Social Work Skills Demonstarted Begining Direct Practice. Boston: Pearson Education, Inc.

Medcom.id. (2020). Pemberdayaan Masyarakat Bantu Penanganan Covid-19. From: https://www.google.coom/amp/s/m.medcoo m.id/amp/8koBpwYb-pemberdayaanmasyarakat-bantu-penanganan-covid-19

Miley, K., O’Melia, M., and DuBois, B. L., (1998). Generalist Social Work Practice: An Enpowering approach (2 ${ }^{\text {nd }}$ ed.). Boston: Allyn and Bacon.

Morales, Armando T., and Bradford W. Sheafor. (2001). Social Work: A Professional of Many Faces, 9th ed. Boston: Allyn and Bacon

Pincus, A., and Minahan, A. (1973). Social Work Practice: Model and Method. Itasca, IL: Peacock Publishers, Inc.

Politeknik Akbara Surakarta. (2020). Di Rumah Aja, Tetapi Tetap Produktif dalam Belajar, Simak Tips Berikut Ini. From: https://www.akbara.ac.id/di-rumah-tetapitetap-produktif-dalam-belajar-simak-tipsberikut-ini/

Raharjo, dkk. 2015. Panduan Praktikum Mikro, Konseling dan Pengembangan Diri. Unpad Press: Bandung

Raharjo, Santoso T. 2015. Keterampilan Pekerjaan Sosial, Dasar-dasar. Unpad Press: Bandung , 2015. Assessment dan Wawancara,

Dalam Praktik Pekerjaan Sosial dan

Kesejahteraan Sosial. Unpad Press:

Bandung , 2015. Dasar Pengetahuan Pekerjaan

Sosial. Unpad Press: Bandung

Rahmi, M. (2020). PENGUATAN PERAN KELUARGA DALAM MENDAMPINGI ANAK BELAJAR DI MASA PANDEMI COVID-19. Jurnal Kreatifitas : Jurnal Ilmiah Pendidikan Islam, 81-105.

Robert \& Greene. 2002. Social Workers Desk Reference. Oxford University Press: New York.
Saleebey, D. (2002). The Strengths Prespective in Social Work Practice $\left(3^{\text {rd }}\right.$ ed.). Boston: Allyn and Bacon.

Schon, Donald. 2017. The reflective practitioner: How professionals think in action, (2017), Basic Book: New York

Sheafor dan Horejsi, (2003). Techniques and Guidelines for Social Work Practice, 6th Edition, Allyn and Bacon)

Shebib, B. (2003), Choices: Counselling skills for social workers and other professionals. Boston, MA: Allyn \& Bacon

Shulman, L. (1999). The Skill of Helping Individuals, Families, Groups, ang Organizatios $\left(4^{\text {th }}\right.$ ed.). Itasca, IL: F. E. Peacock Publishers.

Suparno. 2015. Pembelajaran di Perguruan Tinggi Bergaya Paradigma Pedagogi Refleksi. Yogyakarta: Sanata Dharma University Press

Thompson, (2012) Understanding of Social Work. London: Palgrave.

Tirayoh, V., \& Lintong, D. (2020). Penguatan Ekonomi Rumah Tangga pada Masa Pandemi Covid-19 di Kelurahan Sario Kota Baru Kecamatan Sario Kota Manado. Jurnal Pengabdian Multidisiplin, 34-39.

Wahana, Paulus. Mengenal Pendekatan Paradigma Pedagogi Reflektif Dalam Pendidikan untuk Membangun Manusia yang Cerdas dan Humanis. Jurnal Didaktika. Vol. 5, No. 1 https://journal.uny.ac.id/index.php/didaktika /article/view/11932

Watiknas. (2020). Empat Kelebihan dan Kekurangan Dalam Menerapkan ELearning. Retrieved from Dewan Teknologi Informasi dan Komunikasi Nasional: http://www.wantiknas.go.id/id/berita/empat -kelebihan-dan-kekurangan-dalammenerapkan-e-learning

WHO. (2020, Februari 24). A guide to preventing and addressing social stigma associated with COVID-19. Retrieved from World Health Organization: https://www.who.int/publications/m/item/aguide-to-preventing-and-addressing-socialstigma-associated-with-covid19?gclid=CjwKCAiA2O39BRBjEiwApB2I ku729AJ_ho3RWvG71R_4alUZ40uoQuHG 


\begin{tabular}{|c|c|c|c|c|}
\hline $\begin{array}{c}\text { Jurnal Pengabdian dan } \\
\text { Penelitian Kepada Masyarakat } \\
\text { (JPPM) }\end{array}$ & $\begin{array}{c}\text { e ISSN: 2775 - 1929 } \\
\text { p ISSN: } 2775-1910\end{array}$ & Vol. 2 No.1 & Hal: $56-70$ & April 2021 \\
\hline
\end{tabular}

VjH9MfrgcmmDyGy8sQqL5BoCfM4QAv D_BwE

Wibhawa, B; Raharjo, ST; Santoso, MB. 2019. Dasar-Dasar Pekerjaan Sosial. ITB Press: Bandung

Wibhawa, Humaedi, Riana, Taftazani, Irfan, Rusyidi. Jurnal Penelitian \& PPM ISSN: 2442-448X Vol 4, No: 2 Hal: 129 - 389 Juli 2017

Winahyu, A. I. (2020, Maret 12). Mendikbud Imbau
Sekolah Lakukan Upaya Pencegahan Covid-19. Retrieved from Media Indonesia: https://mediaindonesia.com/read/detail/2961 02-mendikbud-imbau-sekolah-lakukanupaya-pencegahan-Covid-19

Zastrow, Charles, 1995. The Practice of Social work. $4^{\text {th }}$ Edition. Brooks/Cole Publishing Company, California. 